\section{引 用 文 献}

Bolles, R. C., Hulicka, I. M., \& Hanly, B. 1959 Color judgment as a function of stimulus conditions and memory color. Canad. J. Psychol., 13, 175-185.

Bruner, J.S., Postman, L., \& Rodrigues, J. 1951 Expectation and the perception of color. Amer. J. Psychol., 64, 216-227.

Burnham, R. W., \& Clark, J. R. 1955 A test of hue memory. J. appl. Psychol., 32. (3) 164172.

Dunker, K. 1938 The influence of past experience upon perceptual properties. Amer. J. Psychol., 52, 255-265.

Fisher, C., Hull, C., \& Holtz, P. 1956 Past experience and perception: memory color. Amer. J. Psychol., 69, 546-560.

Harper, R.S. 1953 The perceptual modification of colored figures. Amer. J. Psychol., 66, 86 $-89$.

Lenneberg, E. H. 1961 Color naming, color recognition, color discrimination. Percep. Motor Skills, 12, 375-382.

- 1970. 12. 14. 受稿—

\title{
習得と消去における個体内の部分強化効果 ${ }^{1}$
}

$\begin{array}{lllll}\text { 京都大学 } & \text { 高 } & \text { 野 } & \text { 桂 } & \text { 子 }^{2} \\ \text { 京都大学 } & \text { 本 } & \text { 吉 } & \text { 良 } & \text { 治 }\end{array}$

部分強化 (PRF) 群の消去抵抗が連続強化 (CRF) 群 の消去抵抗より大きいことは，いわゆる部分強化の効果 (PRE) として一般に認められている事実である.PRF と $\mathrm{CRF}$ とが同一個体比与兄られ，兵の後，消去が行われ るとき，PRE があらわれない場合がある (Rashotte \& Amsel, 1968)! またしばしば逆のPRE さ方あらわれる ことも专る. PRE は，例党ば白色直線走路で PRF を 与兄，黒色直線走路で CRF を学るとい5 Rashotte (1968）の実験のように PRF と CRF とが継時的に与 えられ，反応の時間が測度として用いられるとき多く みられる。これに対し逆の PRE は, 例豆ば，明るい刺 激のときのレバー反応《は PRF を与充, 暗い刺激のと きのレバー反応似 $\mathrm{CRF}$ を与它るという自由オペラン ト状況でみられる (Pavlik \& Carlton, 1965 ; Pavlik, Carlton, Leher \& Hendrickson 1967). また同時選択 状沉に秃いて，一方で PRF，他方では CRF を与克， 消去にさい乙動物がいずれを選ぶかが問われたとさ，逆 の PRE が見出されている (Divak \& Elliot, 1967).

以上のような事実から，強化のパラドックスといわれた PRE は, 反応の時間を測度とするために生じるのでは ないか.PRF の状況に生体はある特有の適応を示し，

\footnotetext{
1 Within-subjects partial-reinforcement effects in acquisition and extinction.

2 Keiko Takano \& Ryoji Motoyoshi (Kyoto University) 但し, 高野の現在の所属は甲子園女子短期大学で 岁る。
}

それが反応の時間と選択の決定といら二つの反応測度の 間の不一致をもたらするのと考党られる.

本実験の目的は個体がもつ PRF と CRF による二つ の習慣の強さは選択の測度に示されること, 香た, 反応 の時間の測度と選択の測度とを比較し，その相異を明ら かにすることである。

$$
\text { 方法 }
$$

被験体 京大動物飼育センターより得られた生後 34 箅月の実験経験のないウイスター系ラッテ 26 匹( を用いた。実験開始時の体重は 130-150 gm.

装置 $\mathrm{E}$ 型迷路を使用 (Fig. 1), 出発箱, 選択点, 目

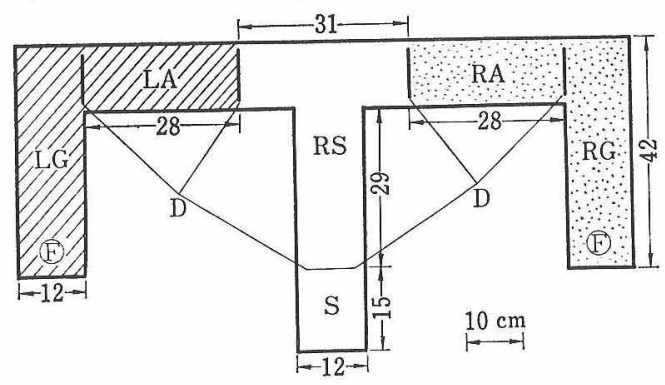

FIG. 1. The apparatus used in this experiment. Notes : $\mathrm{S}=$ starting box. $\mathrm{D}=$ guillotine door. $\mathrm{LA}=$ left arm (black). LG=left goal box. $\mathrm{RA}=$ right arm (white grey). $\mathrm{RG}=$ right goal box. RS=running stem (middle grey). $F=$ food cup. 
標箱，のところにそれぞれギロチンドアーが設けられ た. 出発箱, 中央走路, 選択点は灰色, 左肢执よびそれ に続く目標箱は黒色，それに対し右肢扣よびそれに続く 目標箱梳灰白色であった。目標箱にはそれと同色の直径 $5 \mathrm{~cm}$ の䬲血が扔かれた。

手続き 予備訓練 12 日間, 20 時間の飢餓条件で 1 日 $10 \mathrm{gm}$ の実験用固型飼料が与えられた. その間 1 日 約 3 分間のハンドリングが行われた.

訓練 全動物の半分には左方の目標箱では CRF, 右 方の目標箱では $50 \%$ PRF が与えられた。な特残りの半 分には逆の条件が与えられた。強化としては $0.05 \mathrm{gm}$ のミルクペレット 2 籄が用いられた。 4 匹一組とし, 試 行間隔は最小 2 分であった. 各試行ごとに, 動物を $\mathrm{E}$ 迷 路の出発箱に特き, 走路の方をむくとただらにドアーを ひらいた．動物が出発点に戻ることを妨げるため，ドア 一をくぐりぬけるとただちにドアーを特ろした。つぎに 動物がいずれかの選択肢を選ぶと選択点のドアを, 目標 箱に達すると目標箱のドアーを括らした. 1 日目 4 試行,

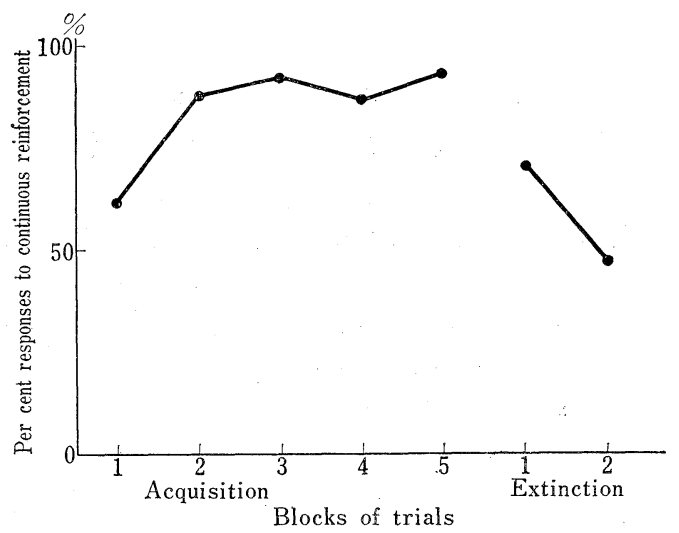

FIG. 2. Per cent choice in acquisition and extinction plotted by 4-day blocks.

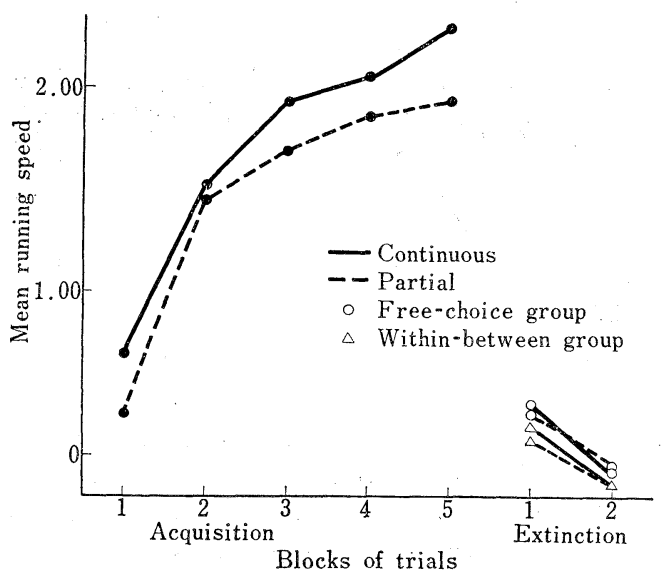

FrG. 3. Mean running speed in acquisition and extinction plotted by 4 -day blocks.
TABLE 1

Distribution of the first free choice to CRF and PRF arms and mean runing speed in the 21 th day of acquisition.

\begin{tabular}{c|c|c}
\hline & Choice response & Running speed \\
\hline To CRF & 96.2 & .603 \\
To PRF & 3.8 & .500 \\
$* * p<.001$ & $* p<.01$ &
\end{tabular}

2 日目 6 試行, 3 日目以後は 1 日 10 試行, 21 日間で合 計 200 試行が与兄られた。 その間 1 日の最初の 2 試行が 自由選択, つぎの 2 試行は最初の 2 試行々逆方向への強 制選択であった。ささらに続く試行では, めらかじめきめ られたパターンに従って, 左右に等しい回数の強制選択 が与えられた。この強制選択は選択肢の 1 万のドアーを あらかじめ開き，他方を閉じることによって操作され た。

消去 習得期閒終了後, 全動物は F 群 (Free choice) とWB 群 (Within-Between) に分けられ，22 日目上 り消去手続きが行われた。すなわち，いずれの側でも強 化は与兄られなかった．習得時と同じく 4 匹一組で行わ れた。 F群（10匹）飞は1日 10 試行 8 日間の自由選択 が与えられた。WB 群 (16 匹) は, 習得時の PRF の側 にの久強制的飞選択させるWBP 群 (8匹) と, CRF の側にのみ強制的に選択させる WBC 群（8匹）とに分 けられた。

習得時，消去時を通じ，自由試行に和ける選択方向 と，全試行の走行時間を反応测度とした．選択方向は動 物が選択点ドアーをくぐることによって決定され，走行 時間としては，出発箱ドアーをくぐりぬけてから目標箱 ドアーをくぐり好るまでの時間が測定された。

\section{結 果}

習得時の選択と走行速度 選択について：その日の最 初の自由選択試行のみを資料とする. 自由選択試行の第 2 試行目は交替行動の影響をうけるため除外された。 2 日目より 21 日目まで 20 日間を，4 日ごとの 5 組にわけ る. 全動物の $\mathrm{CRF}$ 選択率を Fig. 2 飞示す. Fig. 2 に 示されるように習得がすすむれつれて CRF への選択率 は増加する。

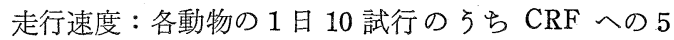
試行の走行速度, PRFへの 5 試行の走行速度がそれぞ れ資料として用いられる。 20 日間を 4 日ごとの 5 組に わけ，全動物の CRF 物よび $\mathrm{PRF}$ への平均走行速度が Fig. 3 に示される. 速度についても CRF への走行速度 がより早くなることが知られる。最終日の試行につい て, $\mathrm{CRF}$ 選択率と, $\mathrm{CRF}$ とRE への速度と, それぞ れの統計的検定の結果を Table 1 飞示す. 習得の最終 期には $\mathrm{CRF}$ がより選択され，その側への走行速度がよ り早いことが見出された. 
TABLE 2

Distribution of the first free choice for free-choice group and mean running speed for free-choice group and within-between group during four days of extinction

\begin{tabular}{l|c|c|c|c}
\hline Days & 1 & 2 & 3 & 4 \\
\hline \multicolumn{4}{l}{ Choice response in free-choice group } \\
\hline To CRF & 85 & 76 & 64 & 58 \\
To PRF & 15 & 24 & 36 & 42 \\
\hline \multicolumn{4}{l}{ Running speed in free-choice group } \\
\hline To CRF & .617 & .577 & .422 & .241 \\
To PRF & .574 & .504 & .346 & .218 \\
\hline
\end{tabular}

Running speed in within-between group

\begin{tabular}{c|c|c|c|c}
\hline To CRF (WBC) & 5.779 & 4.687 & 2.88 & 1.73 \\
To PRF (WBP) & .468 & .345 & .257 & .130 \\
$* * p<.001$ & $* p<.05$
\end{tabular}

消去時の選択と走行速度 $\mathrm{F}$ 群の各動物 1 日 10 試行 の $\mathrm{CRF}$ 選択率の資料を 4 日一組として計 8 日間にわた り Fig. 2 に示す. 10 試行のうち $\mathrm{CRF}$ への 5 試行の走 行速度と PRF への 5 試行の走行速度の資料を 4 日一組 とし計8日間にわたり Fig. 3 に示す. 消去 1 日目より 4 日目末での $\mathrm{CRF} へ$ へ選択率と々の統計的検定, CRF と PRF への走行速度ぶ Table 2 に示される. 消去 2 日目まで動物は明らかに CRF をより多く選択すること が知られる。

WBC 群とWBP 群の 1 日 10 試行の走行速度を 4 日 一組にしてFig. 3 に示す.消去 1 日目から 4 日目までの
選択率, 走行速度招よび両群の比較についての統計的検 定が Table 2 に示される. その結果消去 1 日目に和いて WBC 群の速度がより大であり，PRE は見出されない。 両群について走行時間 1 分を消去規準としてそれまでの 平均試行数を示すと, WBC 群は 38.8 試行, WBP 群 は 32.0 試行でその間に有意差は示されなかった.

以上当実験条件では，選択と反応時間のいずれの測度 に和いても, 逆の PRE がみられた.

\section{引用文 献}

Divak, M., \& Elliot, R. 1967 Effects on extinction, with and without free choice, of degree of experience with stimuli associated with both partial and continuous reinforcement. Psychon. Sci., 7, 255-256.

Pavlik, W. B., \& Carlton, P. L. 1965 A reversed partial-reinforcement effect. J.exp. Psychol., 70, $417-423$.

Pavlik, W.B., Carlton, P.L., Leher, R., \& Hendrickson, C. 1967 A reversed PRE. J. exp. Psychol., 75, 274-276.

Rashotte, M.E. 1968 Resistance to extinction of the continuously reward response in withinsubject partial-reinforcement experiments. J. exp. Psychol., 76, 206-214.

Rashotte, M.E., \& Amsel. A. 1967 The within-S demonstration of a relationship between frustration and magnitude of reward in a differential magnitude of reward discrimination. J. exp. Psychol. 73, 187-195.

- 1970. 1. 19. 受稿— 